\title{
How Just War Theory May Survive Without the Supreme Emergency Exemption
}

\author{
Nathan Colaner \\ University of North Carolina
}

\section{§1. Introduction}

Since the human cost of war is inevitably great, the West has traditionally articulated, defended, and at least nominally practiced a theory of fighting just wars. Unfortunately, this laudable theory is liable to attack because of the widely recognized doctrine of the 'supreme emergency exemption' (SEE). This doctrine states that a nation at war may directly target the civilian population of an enemy nation in an emergency situation, even though such use of force is forbidden by the other rules of just war theory. As a result, just war theory (JWT) appears to offer paradoxical advice, for it says both that civilians may never be targeted, and also that civilians may be targeted in certain circumstances.

Traditional just war proponents such as Michael Walzer' and Brian Orend ${ }^{2}$ both appreciate this problem but insist that it is necessary to retain this paradox, ${ }^{3}$ since the SEE seems to explain many difficult wartime situations. I regard their views as both problematic and unnecessary. They are problematic because they threaten to undermine the credibility of JWT itself. The main rival to JWT is

1 Walzer, Michael. Just and Unjust Wars: A Moral Argument with Historical Illustrations. Basic Books; New York, 2000 Ed.

${ }^{2}$ Orend, Brian. Michael Walzer: On War and Justice. McGill-Queen's University Press; Montreal, 2000 ed.

${ }^{3}$ Orend reclassifies the paradox as a dilemma, but agrees with Walzer that it must remain a central feature of just war theory. 
the flat rejection of the very notion of rules in warfare, henceforth referred to as the 'war is hell' theory. ${ }^{4}$ Walzer and Orend, although it is quite against their intentions, are actually giving credibility to the 'war is hell' theory. This is because its main appeal is the belief that in war, nations are willing to do anything in order to survive. Hence, any attempt to place moral constraints on warfare is hopeless: a war is a struggle for survival, and a struggle for survival knows no rules. Thus, when Walzer and Orend insist that there are times in war when the rules of JWT may be suspended, they are affirming what the 'war is hell' theorist affirms.

Fortuitously, the SEE need not result in paradox. If I can show that the SEE can be incorporated into the traditional rules of warfare in a way that does not create a paradox, I will show that JWT is a coherent theory; and since it is a coherent theory, it is more likely to be accepted. I want to make JWT as appealing as possible, because I agree with Walzer and Orend that it gives expression to many admirable moral intuitions. After briefly describing the main tenets of JWT (\$2), I will describe the SEE through an analysis of two historical examples $(\S 3)$. I will then give an account of Walzer's and Orend's respective attempts to address this paradox, $(\S 4, \S 5)$ and why those responses are insufficient $(\S 6)$. This will lead to my own solution - an expansion of the principle of minimal force $(\S 7)$.

\section{§2. Jus In Bello Principles}

Just war theory has two main components, jus ad bellum (justice in going to war) and jus in bello (justice in fighting the war). This distinction is made necessary because "it is perfectly possible for a just war to be fought unjustly and for an unjust war to be fought in strict accordance with the rules" (JUW 21). A discussion of the principles that decide justice in going to war is not relevant here since the supreme emergency exemption can only be enacted by nations that have already satisfied the rules of jus ad bellum. The supreme emergency exemption, then, is a jus in bello matter. Brian Orend

${ }^{4}$ See Walzer, pp. 29-33. 
extracts two relevant jus in bello principles ${ }^{5}$ from Walzer's writings that are commonly advanced in some form by most theorists, and it is through the relationship of these principles that the supreme emergency exemption emerges. First is the principle of discrimination, which is so-called because it seeks to discriminate between sources of direct harm and sources of indirect harm (or non-harm) within an enemy nation. This principle captures the moral intuition that it is morally wrong to target civilians, and so dictates that attacks must be confined to military personal and bases only:" "All non-harming persons or institutions are thus immune from direct and intentional attack by soldiers" (MW 112). There is of course the difficultly of articulating the moral ground that explains why soldiers, particularly conscripted ones, are deprived of their rights in such a way as to allow them to be targeted. However, it is typically unproblematic in the just war tradition to think that it is wrong to target civilians who are not directly related to the war effort.

Second is the principle of proportionality. This principle is a version of a jus ad bello principle, which "requires that the anticipated moral cost of fighting the war be in line with the moral benefits" (129). ${ }^{7}$ This is a decision that must be made in advance of going to war. In the context of jus in bello, the principle is not very different: "the term proportionality [sic] refers to the total calculus of the balance of good and evil associated with a particular operation or actions in the course of war" (MCW 129). In practice, this means that a nation's strategy must consider whether what will be gained is proportional to what will be lost. For instance, it may be disproportionate to demolish a small Nazi weapons hold if doing so would compromise the safety of many German citizens. This prohibition holds despite the fact that it would be good in an absolute sense to demolish a Nazi weapons hold.

${ }^{5}$ There are more than two, but since the supreme emergency exemption arises in the conflict between the two principles articulated below, I will confine my discussion to them.

${ }^{6}$ Civilians may become a direct threat through by manufacturing weapons. In this case, they lose their 'non-harm' status.

${ }^{7}$ Moral Constraints on War: Principle and Causes. Edited by Bruno Coppieters and Nick Fotion. Lexington Books, London; $2002 \mathrm{ed}$. 
The principle of discrimination and the principle of proportionality can typically be upheld at the same time - but not in every case. The idea of the supreme emergency exemption is that it allows the principle of discrimination to be suspended in favor of the principle of proportionality in the case of an emergency. It is legitimate to claim that there is an emergency when two criteria are met simultaneously. First, the attacked country must face an imminent danger; second, the character of the danger must have the potential to be unusually devastating. ${ }^{8}$ When these two criteria are in play at once, according to just war theory, a nation may target civilians directly if that is the best way to achieve victory in the war. I now turn to an apparent example and then an actual example of the legitimate use of the supreme emergency exemption.

\section{\$3 The Supreme Emergency Exemption}

An interesting way to illustrate the SEE is by giving an example of a misapplication of it. This may be seen in Truman's decision to drop atomic bombs on the Japanese civilian populations in Hiroshima and Nagasaki. ${ }^{9}$ Military intelligence predicted that if the war were to continue under normal conditions (i.e. more invasions of Japanese military bases), a million additional American soldiers and even more Japanese soldiers would be lost before the war would end. Regardless of the accuracy of these predictions, it is easy to imagine how the nuclear bombings of Hiroshima and Nagasaki might have seemed reasonable given that those bombings would end the lives of perhaps 200,000 civilians. Although targeting civilians is typically off-limits, the vastly skewed casualty estimates raised a moral dilemma. A 200,000 civilian loss is by all standards horrific, but when the lives of 2 million or more service members are in the balance, those potential civilian losses appear mercifully small. This was a situation when the principle of discrimination and the principle of propor-

\footnotetext{
${ }^{8}$ See Walzer, pp. 251-255.
}

9 To call Truman's decision a misapplication of the supreme emergency exemption is of course argumentative, since many reasonable people (still) find his decision to be the right one. However, according to orthodox just war theory, especially Walzer, there is no doubt. Truman's actions conflict with just war theory. See pp. 263-68 of Just and Unjust Wars. 
tionality were in clear conflict, and it became necessary to choose one. One could decide to honor the principle of discrimination, and in that case, the civilian bombings would be strictly forbidden. Truman, of course, chose to uphold the principle of proportionality.

At the time, the Japanese threat must have seemed like a supreme emergency. Indeed, Walzer says that in the midst of battle it seems as though "every war is an emergency" (JUW 251). However, he does not believe that there was a genuine emergency in this case. Walzer has said that two things must be present simultaneously in order to justify use of this exemption: both the "imminence of the danger" and the severity of the danger, for it "must be of an unusual and horrifying kind" (JUW 253). Both criteria must be present, for "[n] either one by itself is sufficient as a ... defense of the extraordinary measures extremity is thought to require" (JUW 252). He symbolizes Truman's dilemma: "if we don't $x$, we will do $y$ " (267). That is to say that when Truman decided to bomb the civilian populations, he had other options, such as the afore-mentioned direct military invasions. ${ }^{10}$ For Walzer, this is therefore not a true supreme emergency; that term is reserved for times when the formula is this: "if we don't $x$..., they will do $y$ " (267). This formula underscores the fact that the nation considering action must have no options at all, unless annihilation counts as an option. The lack of options is what makes a difficult wartime decision an emergency, which is not what America faced with regard to Japan in World War II.

To demonstrate what Walzer regards as a legitimate use of the SEE, he turns to another specific historical example, namely, Churchill's decision to bomb civilians on the verge of the Nazi takeover of England. For Walzer, the Nazi threat met both criteria for enacting the SEE, namely, the proximity and serious nature of the danger. In 1940, the Nazi threat was of such a character that Walzer seconds Churchill's statement that "a German victory in World War II 'would be fatal, not only to ourselves, but to the independent life of every small country in Europe" (JUW 254). This state-of-affairs, coupled with the fact that all of England's significant war allies at the time were conquered and that Hitler had already commenced bomb-

${ }^{10}$ There has even been speculation that Japan might have accepted a conditional surrender at that point in the war. 
ings on London, provided a historical example of a country thrust "under the rule of necessity..." (JUW 254).

Thus, Walzer believes that Churchill justifiably ordered the Royal Air Force to begin targeting and bombing the civilians of the city of Dresden. Over the next years, over one million people who were not a direct threat to England were killed or seriously injured by England's decision (JUW 255). The seriousness of the cost of civilian lives is not lost on Walzer, and he does not take such a decision lightly. He never wavers in his belief that even the rightness of such an action can never satisfy our sorrow about the human tragedy. Indeed, he condemned England's continued practice of civilian bombing after the supreme emergency was over and England again found itself in 'normal' wartime horror. It should be pointed out that Walzer is fully aware of what he has said: civilians must not be targeted, but Churchill did the right thing by targeting civilians. I now turn to Walzer's attempted reconciliation of these apparently contradictory statements.

\section{§4. Walzer's "Dirty Hands" Policy}

Walzer maintains that it is necessary to retain this paradox. He even offers $a$ priori criticism of any future attempts at a resolution: "A [rival] moral theory ... might achieve greater coherence, but it would miss or it would repress the reality of war" (JUW 326). The SEE creates a paradox by conflicting with the principle of discrimination: "in supreme emergencies our judgments are doubled, reflecting the dualist character of the theory of war and the deeper complexity of our moral realism; we say yes and no, right and wrong" (JUW 326). But what is the problem with a paradox? Is war not atready a paradox, in which "the world can present us with situations in which there is no honorable or moral course for a man to take..." (JUW 326)? For Walzer, the answer is an emphatic 'yes.' He says that "the world of war is not a fully comprehensible, let alone a morally satisfactory place. And yet it cannot be escaped, short of a universal order in which the existence of nations and peoples could never be threatened" (JUW 327).

This is Walzer's way of saying that the paradox created by the supreme emergency exemption is not particularly shocking, for it is 
merely one more upsetting paradox in an already long line of moral paradoxes of conflict, and we should therefore not be surprised or scandalized that such an exemption exists. However, Walzer still does diagnose a problem here; the problem as he sees it is that the paradox threatens us by threatening not to offer any coherent moral advice. Therefore, the paradox is not itself a problem, but a theory that says 'yes' and 'no' at the same time seems to offer no real-world advice. This is indeed a problem for Walzer, because the raison d'etre of just war theory is to offer practical advice that guides warfare in such a way that limits violations of human rights as much as possible. If such a theory said 'yes' and 'no' at the same time, it might be condemned on the grounds that it would paralyze the nation that must act.

Walzer recognizes this problem and attempts to remedy it by showing how it is possible after all to derive practical moral advice from such a state of affairs via his 'dirty-hands policy.' The dirty hands in question are the dirty hands of those who ordered and carried out the bombings: "What are we to say about those military commanders (or political leaders) who override the rules of war and kill innocent people in a 'supreme emergency'?" (JUW 323). These commanders and leaders have lived out the paradox by doing "what was necessary and right [and] also wrong" (JUW 324, my italics). Decision-makers in a supreme emergency "must opt for collective survival and override those rights that have suddenly loomed as obstacles to survival" (JUW 326). The catch is that "they are [not] free of guilt when they do that,... And they can only prove their honor by accepting responsibility for those decisions and by living out the agony" (UUW 326). That is, their hands are dirty, and indelibly so, for there is no relief for their guilt.

In Walzer's example, Arthur Harris, the commander of the Royal Air Force at the time, is the unfortunate chap who took the brunt of the impossible situation of living the paradox: "After the strategic air offensive ended in mid-April [1945], Bomber Command was slighted and snubbed; and Harris, unlike other well-known commanders, was not rewarded with a peerage" (JUW 324). Furthermore, among the many plaques commemorating World War II heroism, "the bomber pilots, though they suffered far heavier casualties, have no plaque" (JUW 324). Moreover, this was not an administrative oversight, but "a 
deliberate policy that has moral significance and value" (JUW 324). That is, Harris did what was necessary, and therefore right. He had also, however, put an end to the lives of countless innocents, which is why his hands were 'dirty' or 'bloody.' Harris did what is both right and wrong at the same time. His actions were necessary but shameful, and thus not worthy of honor. With the exception that Churchill should have also been thrown in with this 'dirty-handed' lot, Walzer approves of England's policy. This is Walzer's solution to how the supreme emergency exemption can offer real-world moral advice even though it makes us say "yes" and "no" at the same time: a nation must do what is necessary when faced with a genuine emergency, but the perpetrators of civilian deaths should not be honored, for it is not fitting to honor disgraceful actions. By overriding the principle of discrimination, the supreme emergency creates a paradox, but not a 'paralyzing' paradox: a nation can indeed successfully enact the supreme emergency exemption, as England showed in World War II.

\section{\$5. Orend's Doctrine of the Moral Dilemma}

Orend recognizes the need for a SEE, but criticizes Walzer's attempt to incorporate it into JWT. He claims that viewing this state of affairs in its moral aspect alone is too limited, for the 'prudential' perspective must be added: "Morally, a supreme emergency is a terrible tragedy. Prudentially, it is a struggle for survival" (JWT 149)." Significantly, Orend is convinced that this removes the paradoxical standing of the SEE, for his theory does not give "the right to do wrong, and/or a duty to violate duty," as Walzer's does (JWT 149). In Walzer's theory, targeting civilians is both just and unjust. Orend rejects this idea: "if you do wrong, you do wrong, even under the pressure of supreme emergency conditions" (JWT 149). For Orend, this state of affairs is more accurately described as a tragic dilemma rather than a paradox, for both options are tragedies. Orend points out that there is only 'wrong' here, because it is morally wrong to murder the innocent civilians of your enemy whatever the reason, but it is also morally wrong to stand by and allow your own civilians

"Just War Theory: A Reappraisal. Edited by Mark Evans. New York: Palgrave Macmillan, 2005 ed. 
to be slaughtered. In a true SEE, this is what would happen if the offending nation were allowed to be victorious.

Having reclassified the paradox as a dilemma, Orend turns to the 'prudential' perspective, from which "a supreme emergency is a desperate, Hobbesian struggle for survival" (JWT 149). What he does is merely to recommend rules that provide guidance for the use of a supreme emergency exemption. ${ }^{12}$ Orend thus believes that there is not a paradox to live, but a dilemma to be navigated. He believes that by giving sensible direction to a nation's decision to choose one horn of the dilemma, he has satisfied the critics of the supreme emergency exemption.

\section{\$6. Critique of Walzer and Orend}

In Walzer's view, the problem with the paradox is not that it exists, but that it seems to be unable to offer any coherent, real-world moral advice. His 'dirty hands' policy is an attempt to resolve this issue by articulating rules for how a nation may actually target civilians directly in drastic circumstances. Thus, he attempts to show that it is possible after all to derive practical recommendations from this state of affairs, thinking that the success of this argument has justified the existence of the supreme emergency exemption. Although Orend criticizes Walzer, his solution is not much different; he renames the paradox a dilemma, and then offers practical advice to a nation attempting to navigate the dilemma.

Walzer and Orend, however, have both missed the point. The paradox created by the SEE is not troubling primarily because it threatens to offer no actionable advice, but because it threatens to undermine just war theory itself. Theories in general with paradoxes, exemptions, exceptions, or tragic dilemmas are destined for rejection. Those who would disparage the very notion of rules within warfare as self-defeating-the 'war is hell' theorists-could use Walzer's own writings as proof that there is no sense to aspire to an ideal of just warfare. Walzer, in another part of his book, aptly describes General Sherman's utterance that 'war is hell':

${ }^{12}$ See Just War Theory, pp. 149-151. 
His maxim sums up, with admirable brevity, a whole way of thinking about war... In his view, war is entirely and singularly the crime of those who began it, and soldiers resisting aggression (or rebellion) can never be blamed for anything they do that brings this victory closer. The sentence War is hell is doctrine, not description: it is a moral argument, an attempt at self-justification. Sherman was claiming to be innocent of all those actions (though they were his own actions) for which he was so severely attacked (JUW 32).

Despite its ubiquitous misuse, the saying 'war is hell' was not originally intended as a description of the horrors of warfare. Rather, it was advanced as explanation of questionable conduct in warfare. Thus, 'war is hell' can be thought of as a rival doctrine to just war theory-one that states that the end justifies the means, and therefore, any action taken toward a just goal is acceptable. This would of course, include even the direct targeting of civilians. This theory could recognize the principles of going to war advanced by just war theory, but it holds that once a war has begun, all of the actions done committed by a nation that adhered to the principles of jus ad bellum are justified. The just war principles of jus in bello, however, are senseless.

Walzer and Orend have unintentionally given powerful justification for the 'war is hell' theory of fighting a war. Walzer has shown, through his dirty hands policy, how it is simultaneously possible to acknowledge the paradox created by a supreme emergency exemption and yet act in the face of it. Since Walzer saw this as the only obstacle to accepting the paradox, he believes that he has solved the problem. Orend's theory supports the 'war is hell' doctrine to the same degree. He has claimed it is dilemma of which both horns are morally wrong (targeting enemy civilians, allowing civilians of one's own nation to be killed). Therefore, the only question is a prudential one. However, this is exactly Sherman's point. War inevitably brings these dilemmas with no morally right horn, and so it is senseless to make this a moral issue. When fighting a war, there are only prudential concerns about how to win it. If this is the debate, Sherman's 'war is hell' theory is better than traditional JWT. 


\section{§7. Rethinking the Principle of Discrimination}

As a supporter of JWT, my task is clear: the paradox must be removed, or Sherman's theory will have to be taken seriously. The key is to discover a moral principle that is shared by both the principle of discrimination and the principle of proportionality. Following the humanitarian intervention tradition, we may identify this principle as the principle of minimal force. ${ }^{13}$ As I formulate it, the principle of minimal force simply states that once a nation has met all the criteria of jus ad bellum, when in the war it must always use the least amount of force possible to achieve victory. This preserves the relevant moral intuitions expressed in the principles of discrimination and proportionality, since they were obviously both formulated specifically in order to minimize the violence involved in fighting a war.

Since there is a single principle under-girding both of these principles, there is no reason that we should not explicitly recognize this 'principle of principles'; I submit, therefore, that the principle of minimal force should be acknowledged as the locus of all jus in bello principles. We can subsequently re-categorize the principles of discrimination and proportionality as sub-principles. That is, they are principles that seek to give detail to the principle of minimal force, but they do not establish rules that extend the principle of minimal force. This is to make these sub-principles conditional. In Walzer's formulation, however, the principle of discrimination sounds like the $11^{\text {th }}$ commandment: 'Thou shalt not target civilians.' Therefore, when a commander-in-chief such as Churchill is forced to target civilians, a paradox is created. However, in my reformulation, the only rule that is absolute is the principle of minimal force. The principle of discrimination is appropriately reformulated as a conditional: "You may never target civilians except in the case of a supreme emergency."

If a wartime situation is a genuine emergency, then the principle of minimal force justifies the disregard of the principle of discrimination, because in that case, the minimum amount of force necessary to quell, say, the Nazi invasion, is specifically to bomb German civil-

${ }^{13}$ See, for example, the UN-sanctioned report The Responsibility to Protect, issued by the International Commission on Intervention and State Sovereignty (ICISS): "The Responsibility to Protect," Ottawa: The International Development Research Centre, 2001. 
ians. In normal wartime, when we make a special effort not to target civilians, we are also using the principle of minimal force, and thus fighting justly. This is to abandon the schizophrenia of a paradox for the coherence of a single rule. It is for this reason that my suggestion is an improvement of the theories of Walzer and Orend, for they have no reason to expect someone to believe in a theory that violates its own rules, especially when there is a completely coherent rival theory-'war is hell'-asking for our consideration.

\section{§8. State of the Argument}

There is a potential complaint that this change is merely a semantic change. That is, no actual action or moral recommendation changes by substituting the principle of minimal force, and so my proposed change may be seen to be an unimportant one. This complaint misses the point entirely, for the beauty of my proposal is precisely that is does not need to make new or different moral recommendations for how, example, Churchill should have directed the Royal Air Force in 1940. Rather, the principle of minimal force removes the awkward acknowledgement of a paradox created by the conflict between the principle of discrimination and the supreme emergency exemption. It is able to do this because this principle is large enough to contain the intuitions behind both the principle and the exemption. The result of this change is not a new set of requirements for acting in the face of imminent and horrendous danger, but the greater likelihood that just war theory will be taken seriously. It is my hope that this semantic change will cause some to rethink their adoption of the 'war-is-hell' theory. I regard just war theory's intuitions as laudable, and they should be preserved and advanced. This has the best likelihood of happening if my suggestion is incorporated. 